\title{
Penggunaan Model PACE dalam Pembelajaran Geometri Topik Bangun Ruang
}

\author{
Tanti Listiani \\ Fakultas Ilmu Pendidikan, Universitas Pelita Harapan \\ Lippo Village, Tangerang, Banten, Indonesia \\ tanti.listiani@uph.edu
}

Artikel diterima: 24-01-2020, direvisi: 26-09-2020, diterbitkan: 30-09-2020

\begin{abstract}
Abstrak
Masih terdapat konsep pada Geometri yaitu bangun ruang yang masih kurang dipahami oleh mahasiswa PGSD. Untuk memecahkan permasalahan tersebut, maka dosen menerapkan model pembelajaran yang mendorong mahasiswa untuk dapat mempelajari bangun ruang dengan efektif. Salah satu model pembelajaran yang dapat digunakan adalah Model PACE. Model PACE memiliki empat langkah yaitu Project, Activity, Cooperative dan Experience. Melalui empat tahapan ini mahasiswa dituntut untuk membuat suatu proyek pembelajaran yaitu membuat video pembelajaran. Metode yang digunakan adalah deskriptif dengan sampel penelitian 90 mahasiswa yang dibagi menjadi 2 kelas. Hasil dari penerapan model PACE adalah mahasiswa dapat membuat alat peraga matematika yang menarik. Selain itu penggunaan model PACE juga dapat membantu mahasiswa dalam menghadapi tantangan sebagai guru SD yang kreatif khususnya dalam mengajar Geometri materi bangun ruang. Hal yang perlu diperhatikan adalah dosen sebagai pendidik perlu mendukung agar tahapan yang terdapat pada model PACE dapat terlaksana dengan baik.

Kata Kunci: Bangun Ruang, Geometri, Model PACE
\end{abstract}

\section{Using the PACE Model in Geometry Learning Build Space Topic}

\begin{abstract}
There is still a concept in geometry, namely the shape of a space that is still poorly understood by PGSD students. To solve this problem, the lecturer applies a learning model that encourages students to be able to study building space effectively. One of the learning models that can be used is the PACE Model. The PACE model has four steps, namely Project, Activity, Cooperative, and Experience. Through these four stages, students are required to make a learning project, namely making learning videos. The method used is descriptive with a research sample of 90 students divided into 2 classes. The result of applying the PACE model is that students can make interesting mathematics teaching aids. Besides, the use of the PACE model can also help students face challenges as creative elementary teachers, especially in teaching geometry in building materials. The thing to note is that lecturers as educators need to support so that the stages contained in the PACE model can be carried out well. Keywords: Build Space, Geometry, PACE Model
\end{abstract}




\section{Pendahuluan}

Matematika merupakan suatu subyek pelajaran yang diajarkan pada semua jenjang sekolah, dari tingkat sekolah dasar hingga di perguruan tinggi (Susanto, 2013). Bukan tanpa alasan kenapa pemerintah Indonesia mewajibkan masyarakat di Indonesia untuk mempelajari matematika sejak dari tingkat dasar sampai perguruan tinggi, karena memang matematika ini sangat penting untuk dipelajari dan dikuasai.

Salah satu matakuliah yang diperoleh oleh mahasiswa PGSD UPH adalah mata kuliah Geometri. Geometri merupakan salah satu cabang ilmu dari matematika yang mempelajari tentang bangun datar dan bangun ruang (Kurniasih, 2017). Matakuliah geometri memiliki keunikan bahwa seseorang dapat juga mempelajari matematika dengan mengagumi Sang Pencipta di samping mempelajari matematika secara konten saja (Saragih, Tamba dan Hidayat, 2019). Mengingat mahasiswa PGSD adalah mahasiswa yang diharapkan nantinya dapat memiliki kemampuan untuk mengajarkan materi matematika di tingkat sekolah dasar. Pemahaman mahasiswa calon guru sekolah dasar akan Geometri sangat diperlukan (Sundawan, Irmawan, \& Sulaiman, 2019). Hal ini dikarenakan mata kuliah Geometri diharapkan dapat membekali mahasiswa dalam mengajarkan materi Geometri seperti bangun ruang.

Menurut Fabiyi (2017), terdapat 3 unsur utama dalam pembelajaran
Geometri yaitu waktu, materi pengajaran dan metode yang digunakan. Ketiga hal ini sebaiknya dilakukan dengan seirama, dan dosen sebagai fasilitator hendaknya memadukan ketiga hal ini secara seimbang dan luwes. Menurut Arbain dan Shukor (2015), dalam belajar Geometri, dibutuhkan suatu kesempatan kepada mahasiswa untuk dapat mengobservasi, mengeksplorasi, mencoba serta menemukan prinsip-prinsip Geometri melalui aktivitas informal (Sholihah \& Afriansyah, 2017) dan melanjutkan ke kegiatan formal dengan berkaitan dalam kehidupan sehari-hari mereka.

Secara umum, salah satu kemampuan Geometri yang harus dimiliki siswa menurut NCTM (2000) adalah aplikasi transformasi dan menggunakannya secara simetris untuk menganalisis situasi matematika serta menggunakan visualisasi, penalaran spasial, dan model Geometri untuk memecahkan permasalahan. Saat belajar Geometri, seseorang mampu untuk dapat memvisualisasikan, menggambarkan, serta membandingkan berbagai bangun Geometri dalam berbagai posisi (Mulyo, Sari, \& Syarifuddin, 2019; NCTM, 2000), sehingga dapat dengan mudah dalam memahaminya.

Supaya pembelajaran Geometri lebih bermakna dan dapat menstimulus mahasiswa untuk menghasilkan suatu karya inovatif, maka pada penelitian ini menggunakan model Project, Activity, Cooperative, Exercise (PACE). Menurut Lee 
(1999), pembelajaran model PACE merupakan model pembelajaran konstruktivisme yang berdasarkan pada prinsip: (1) Siswa belajar lebih baik dengan mengkonstruksi pengetahuan mereka sendiri melalui proses terbimbing, (2) Latihan dan umpan balik adalah unsur penting memahami konsep baru, dan (3) Pemecahan masalah secara aktif dalam kelompok mengembangkan pebelajar menjadi aktif.

Model PACE menyediakan sebuah kerangka kerja untuk memadukan proyek dan lembar kerja yang diberikan kepada siswa bersifat kooperatif. Model ini menempatkan siswa sebagai pusat belajar, guru sebagai fasilitator yang memimpin dan memandu siswa untuk menemukan serta memahami konsep baru (Dasari, 2009). Selain itu, siswa juga memiliki kesempatan yang luas untuk bekerja sebagai sebuah tim yang akan menuliskan serta menyampaikan laporan hasil kerjanya dalam presentasi di depan kelas (Lee, 1999). Menurut Lee (1999) dibandingkan dengan lingkungan belajar kelas konvensional, suatu lingkungan belajar dengan model PACE menyediakan banyak kesempatan kepada siswa dalam mengembangkan kemampuan penalaran statistis mereka, untuk mengeksplorasi, mencari solusi, mengkomunikasikan gagasan, mengadaptasi prosedur penyelesaian, serta memiliki kesempatan untuk mempelajari proses statistis.

Kegiatan pembelajaran yang diberikan berkaitan dengan membuat suatu proyek yang dikerjakan oleh mahasiswa dimana mereka ditugaskan secara berkelompok untuk membuat video pembelajaran. Video pembelajaran yang dibuat berisikan tentang materi Geometri yaitu bangun ruang, seperti cara menemukan luas dan volume bangun ruang beserta soal-soal latihannya. Tujuan pemberian tugas ini adalah agar mahasiswa dapat berlatih bagaimana dalam membuat video pembelajaran yang menarik, seperti saat ini siswa lebih suka dengan pembelajaran yang berkaitan dengan video pembelajaran. Berdasarkan hasil penelitian yang dilakukan oleh Janah, Sulasmono dan Setyaningtyas (2019) mengatakan bahwa video pembelajaran merupakan salah satu media pembelajaran yang dapat digunakan untuk menunjang pembelajaran. Siswa dengan gaya belajar audiovisual akan mudah menangkap apa yang diajarkan jika hal yang dia pelajari berkaitan dengan video yang berisikan animasi dan terdapat suara di dalamnya (Setianingrum, 2017).

Melalui hal tersebut maka pada mata kuliah Geometri ini, diberikan model pembelajaran PACE. Pada tahap Project mahasiswa diberikan tugas untuk membuat video pembelajaran, pada tahap Activity mahasiswa akan melakukan aktivitas di depan kelas untuk membuktikan secara langsung bagaimana cara menemukan luas permukaan dan volume suatu bangun ruang, dilanjutkan tahap Cooperative yaitu mahasiswa akan bekerjasama mendiskusikan materi yang 
sedang dipelajari dan pada tahap Exercise mahasiswa akan berlatih mengerjakan soal. Aktivitas dalam Model PACE bertujuan untuk mengenalkan mahasiswa terhadap informasi atau konsep-konsep yang baru (Suryana, 2013).

Hasil penelitian yang dilakukan oleh Rahman dan Yunita (2018) menyimpulkan bahwa model PACE dapat meningkatkan kemampuan pembuktian matematika pada materi geometri pada kelas VII SMP. Melihat keberhasilan model PACE ini, maka maka pada penelitian ini akan mendeskripsikan mengenai bagaimana implementasi dari Model PACE pada matakuliah Geometri topik bangun ruang, lebih fokus kepada bagaimana mahasiswa dalam merancang video pembelajaran.

\section{Metode}

Metode penelitian dalam penelitian ini adalah metode deskriptif, sementara sampel yang digunakan dalam penelitian ini diperoleh dengan cara purposive sampling (Arikunto dalam Putra, 2015). Hal ini dilakukan karena di semester ganjil tahun ajaran 2019/2020 hanya prodi PGSD yang mendapatkan mata kuliah Geometri, sehingga penelitian dilaksanakan pada bulan November-Desember 2019.

Adapun instrumen yang digunakan dalam penelitian ini adalah rubrik penilaian proyek pembuatan video pembelajaran yang telah dikerjakan oleh mahasiswa dalam kelompok. Terdapat 9 indikator penilaian dari video pembelajaran, dan dalam penskorannya yaitu 4, 3, 2 dan 1 yang berarti skor 4 adalah skor tertinggi dan skor 1 adalah paling rendah. Teknik analisis data yang digunakan adalah deskriptif dengan beberapa penjelasan yang disajikan secara kuantitatif berdasarkan hasil penghitungan pada rubrik penilaian.

\section{Hasil dan Pembahasan}

Permasalahan yang sering terjadi adalah saat praktik mengajar di lapangan, mahasiswa mengalami kesalahan konsep saat mengajarkan materi Geometri. Saat ditanya bagaimana cara memperoleh rumus-rumus untuk mendapatkan luas permukaan dan volume bangun ruang, sebagian besar mahasiswa masih bingung untuk menjawabnya. Berangkat dari masalah ini, maka sebagaimana seorang mahasiswa yang kelak akan menjadi guru $\mathrm{SD}$, penting untuk mahasiswa memahami Geometri dengan lebih baik. Salah satu model pembelajaran yang diterapkan untuk membantu mahasiswa mempelajari materi dengan baik adalah dengan menggunakan model PACE. Model PACE memililiki kepanjangan model Project, Activity, Cooperative, Exercise. Poin penting dalam pembelajaran ini adalah, mahasiswa dituntut untuk aktif belajar dengan mengalami sendiri pengalaman belajarnya. Sebagaimana mestinya, seorang mahasiswa harus memiliki kemandirian untuk belajar dan aktif dalam mencari informasi-informasi yang berkaitan dengan pembelajaran yang sedang dikerjakan. Model PACE cocok 
diberikan kepada mahasiswa, karena model ini menuntut mahasiswa untuk aktif membuat proyek pembelajaran, serta mahasiswa dapat berlatih secara mandiri untuk memahami proses pembelajaran yang ada. Berikut ini adalah langkahlangkah penggunaan model PACE di kelas Geometri untuk angkatan 2017 Prodi PGSD UPH.

Langkah pertama yaitu Project. Pada langkah ini, mahasiswa diberi tugas oleh dosen untuk membuat suatu proyek pembelajaran. Proyek pembelajaran yang diberikan adalah membuat video pembelajaran. Menurut Daryanto (2016) menyatakan bahwa media video mampu memberikan visualisasi materi dengan baik serta membantu guru dalam menyampaikan informasi atau materi secara dinamis (lihat gambar 1 ).

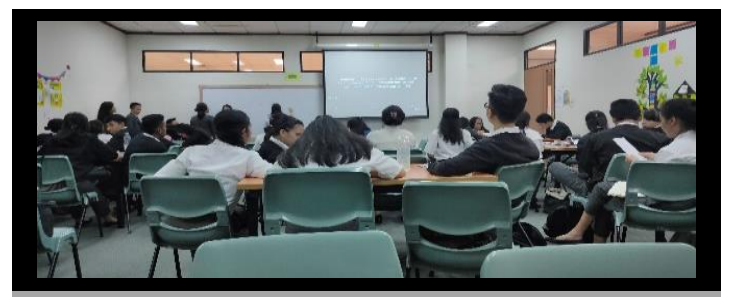

Gambar 1. Foto Kegiatan.

Video pembelajaran yang dibuat oleh mahasiswa berisikan materi-materi yang terdapat pada Geometri khususnya adalah bangun ruang. Pada materi bangun ruang, terdapat sub topik materi yang kemudian materi tersebut dibagikan kepada mahasiswa. Mahasiswa mengerjakan proyek ini secara berkelompok, yaitu satu kelompok terdiri dari 5-6 mahasiswa. Pembentukan kelompoknya dilakukan secara heterogen mulai dari nilai matematika tertinggi sampai terendah dan jenis kelaminnya. Pembentukan kelompok berdasarkan nilai mata kuliah matematika yang diperoleh di semester sebelumnya. Tujuan pembentukan kelompok secara heterogen ini adalah agar mahasiswa dapat saling membantu dan saling bertukar pikiran mengenai ide-idenya dalam membuat proyek akhir.

Langkah kedua adalah Activity. Pada langkah ini, mahasiswa yang terlibat dalam pembelajaran melakukan aktivitas di kelas yaitu mempresentasikan hasil pembuatan proyeknya yaitu video pembelajaran. Mahasiswa dalam kelompok tidak hanya menampilkan video pembelajarannya, namun mahasiswa juga mempresentasikan video pembelajaran tersebut (lihat gambar 2). Mahasiswa menyediakan alat peraga langsung untuk memudahkan pembelajaran. Bukan suatu hal yang sia-sia jika pembelajaran yang dilakukan menggunakan dua media yaitu berupa video pembelajaran dan alat peraga nyata. Karena dengan diberikannya dua media ini, mahasiswa dapat berlatih untuk menyiapkan media pembelajaran yang nantinya dapat digunakan saat mengajar di lapangan. Hal yang menjadi kendala saat mahasiswa praktik mengajar di lapangan adalah terkadang media yang digunakan tidak sesuai dengan kondisi di lapangan. Misalkan mahasiswa ingin menggunakan video pembelajaran di kelas, namun kondisi kelas yang digunakan tidak mendukung adanya fasilitas untuk menampilkan video tersebut. Dengan 
adanya hal inilah, maka dibutuhkan keahlian lain dari mahasiswa. Tidak memungkiri jika masih banyak sekolah yang tidak menyediakan fasilitas LCD di setiap ruang kelasnya. Selain menggunakan variasi metode pembelajaran, mahasiswa juga dapat memanfaatkan alat peraga yang bisa didapatkan dari benda-benda sekitar. Misalkan belajar tentang kubus, maka mereka dapat memanfaatkan kardus yang berbentuk menyerupai bangun ruang tersebut. Banyak contoh-contoh benda sekitar yang termasuk dalam jenis-jenis bangun ruang. Benda-benda inilah yang dapat dimanfaatkan untuk membantu pemahaman siswa dalam mempelajari Geometri topik bangun ruang.

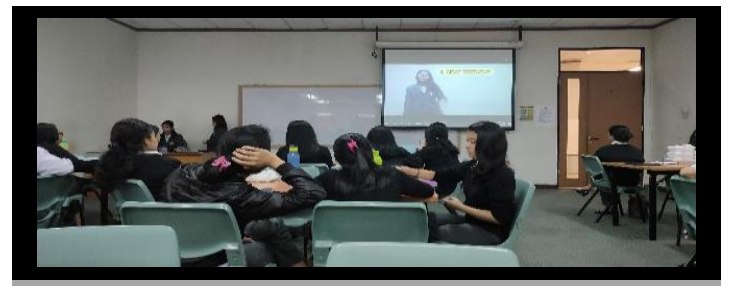

Gambar 2. Foto Kegiatan Presentasi.

Langkah ketiga adalah Cooperative. Pada langkah ini, mahasiswa duduk secara berkelompok di kelas untuk saling mendiskusikan materi yang ada. Hal yang didiskusikan berisikan materi-materi yang terdapat pada bangun ruang. Mahasiswa akan saling bertukar pikiran mempelajari bagaimana memperoleh suatu rumus serta bagaimana jika diterapkan saat pengajaran nanti. Mahasiswa dituntut untuk memahami materi bangun ruang secara konseptual bukan hanya sekedar menghafal. Macam-macam jenis bangun ruang sebenarnya saling berkaitan antara satu dengan lainnya. Seperti contoh, bangun ruang kubus adalah sebenarnya prisma dengan alas dan atap yang berbentuk segi empat, dan masih ada keterkaitan antar jenis bangun ruang lainnya. Hal ini penting untuk dipahami oleh mahasiswa, karena berdasarkan hasil diskusi dengan mahasiswa, mereka mengaku bahwa sebagian besar cara mengajar guru matematika dulu adalah menggunakan cara yang monoton yaitu langsung memberikan rumus. Mahasiswa hendaknya memberikan metode pengajaran yang bervariatif dan bermakna. Mahasiswa calon guru perlu belajar dan berani memberikan cara pengajaran yang berbeda, karena biasanya apa yang dilihat saat belajar di bangku sekolah menengah rentan untuk ditirukan. Hal yang tidak baik yang diperoleh dari gurunya di masa lampau, perlu untuk diperbaiki sebagai guru di masa depan. Mahasiswa dituntut mampu memberikan inovasi pembelajaran yang lebih efektif dan bermakna khususnya untuk materi Geometri yang identik dengan visual (lihat gambar 3).

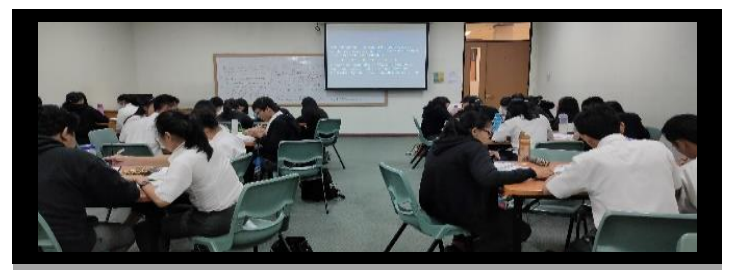

Gambar 3. Foto Kegiatan Kelompok.

Langkah terakhir adalah Exercise. Pada langkah ini, mahasiswa diberi kesempatan untuk mengerjakan latihan. Latihan yang dikerjakan berkaitan dengan materi yang 
dipelajari dipertemuan kuliah. Soal-soal latihan yang disusun adalah soal yang berisikan soal dengan tingkat kesulitan mudah, sedang dan sulit. Pada tahap ini, mahasiswa masih diperbolehkan untuk berdiskusi karena pada kelas Geometri ini mahasiswa juga dibekali dengan kelas responsi. Di kelas responsi, mahasiswa akan difokuskan dengan adanya banyak latihan soal. Semisal di pertemuan ke 9 adalah membahas mengenai kubus dan balok, maka saat kuliah mahasiswa akan belajar secara teori dan sedikit latihan. Untuk latihan yang lebih banyak akan diberikan di kelas responsi, yaitu di luar pertemuan matakuliah (lihat gambar 4).

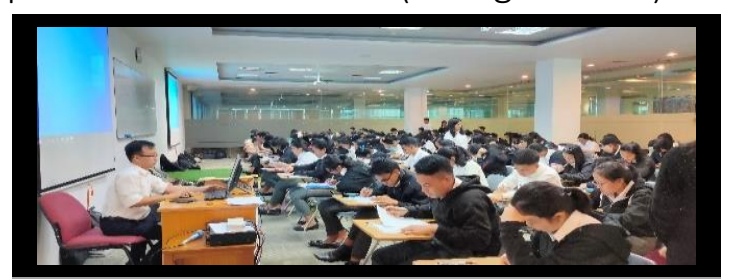

Gambar 4. Foto Kegiatan.

Untuk melihat keberhasilan model pembelajaran, terutama dalam membuat proyek video pembelajaran. Adapun desain media pembelajaran yang dapat digunakan oleh mahasiswa untuk membuat video animasi yang menarik dan bermakna. Video pembelajaran Geometri berbasis video animasi ini didesain dengan menggunakan software microsoft power point. Software ini sangat mudah didapatkan, karena sebagian besar mahasiswa memiliki software ini tanpa menginstal lagi aplikasi baru di komputer mereka.
Pada pembuatan video ini, mahasiswa diminta untuk melakukan tiga langkah dari tahap desain produk video, yaitu:

\section{a. Tahap Pra Produksi}

Pada tahap ini, mahasiswa diberikan materi yang berbeda-beda untuk tiap kelompoknya. Seperti materi kubus, balok, prisma, limas, kerucut, tabung dan bola. Setelah setiap kelompok mendapatkan materi, selanjutnya anggota kelompok mencari sumbersumber materi secara mandiri. Materi yang diperoleh disesuaikan dengan kompetensi dan tujuan pembelajaran. Selanjutnya setiap kelompok akan menunjuk anggota kelompoknya untuk saling membagi tugas dan bagiannya masing-masing, yaitu menunjuk anggotanya untuk berperan sebagai pengisi suara, editor, dan membuat alat peraga. Jika masing-masing sudah selesai mengerjakan bagiannya, kemudian akan dilanjutkan pada tahap produksi.

\section{b. Tahap Produksi}

Pada tahap ini proses penganimasian berlangsung. Software yang digunakan dalam proses ini adalah Microsoft Power Point. Anggota kelompok akan saling bekerja sama untuk membuat slide di Microsoft Power Point, membuat animasi-animasi yang sesuai dan memberikan efek suara dengan disesuaikan dengan slide yang mereka jelaskan. Microsoft Power Point adalah software yang sangat familiar dikalangan mahasiswa, karena 
kebanyakan

mahasiswa

menggunakannya untuk presentasi. Namun ternyata Microsoft Power Point juga dapat digunakan untuk membuat video pembelajaran. Microsoft Power Point yang terbaru menyajikan banyak animasi yang lebih bervariatif dan sebagian besar mahasiswa mampu mengoperasikan software ini.

\section{c. Tahap Pasca Produksi}

Pada tahap ini semua video yang telah dibuat dan dianimasikan pada tahap produksi digabungkan dan diberi efek suara yang dibutuhkan, setelah itu dilakukan proses rendering.

Untuk melihat keberhasilan mahasiswa dalam membuat video pembelajaran, maka dilakukan penilaian untuk video pembelajaran yang sudah dibuat oleh mahasiswa. Adapun indikator penilaian yang digunakan disajikan pada table 1 berikut:

Tabel 1.

Indikator Penilaian Video

\begin{tabular}{|l|c|}
\hline \multicolumn{1}{|c}{ Indikator Penilaian Video } \\
\hline 1 & $\begin{array}{c}\text { Judul video alat peraga } \\
\text { judul video alat peraga }\end{array}$ \\
\hline 3 & $\begin{array}{c}\text { Kemampuan presenter dalam } \\
\text { menjelaskan di video pembelajaran }\end{array}$ \\
\hline 4 & $\begin{array}{c}\text { Keterkaitan video alat peraga dalam } \\
\text { belajar matematika }\end{array}$ \\
\hline 5 & Kemampuan dalam mengeksplorasi \\
\hline 6 & Keseluruhan video alat peraga \\
\hline 8 & Pembagian subtopik pada video \\
\hline 9 & $\begin{array}{c}\text { Kemampuan kelompok dalam } \\
\text { memplaskan topik serta dalam }\end{array}$ \\
\hline
\end{tabular}

Untuk penilaiannya adalah, setiap kelompok akan mendapatkan skor tertinggi 4 dan skor terendah adalah 1 . Sebagai contoh adalah misalkan indikator nomor 4 yaitu kelompok mampu mengaitkan video alat peraga dengan pembelajaran matematika. Jika ia mampu mengaitkan dengan baik maka kelompok tersebut akan mendapatkan skor 4.

Berikut ini adalah hasil penilaian rubrik pembuatan video pembelajaran. Untuk kelas 17IDIP dibagi menjadi 8 kelompok yang terdiri dari 5-6 mahasiswa. Kelas ini mendapatkan rata-rata nilai yaitu 87,53. Sedangkan kelas 17IDIQ, juga dibagi menjadi 8 kelompok dengan tiap kelompok memiliki anggota 5-6 mahasiswa. Rata-rata nilai yang diperoleh untuk kelas 17IDIQ adalah 94,26. Terdapat sedikit perbedaan rata-rata nilai pembuatan proyek akhir antara kelas 17IDIP dan 17IDIQ, dimana kelas 17IDIQ memiliki rata-rata yang lebih tinggi daripada kelas 17IDIP. Hasil analisis penilaian proyek pembuatan video disajikan pada table 2 berikut.

Tabel 2.

Rata-rata Nilai Video Per-Kelas

\begin{tabular}{|l|c|c|}
\hline \multicolumn{1}{|c|}{ Indikator } & Kelas 17IDIP & Kelas17IDIQ \\
\hline 1 & 77,78 & 86,67 \\
\hline 2 & 93,89 & 100 \\
\hline 3 & 87,78 & 93,89 \\
\hline 4 & 93,89 & 97,22 \\
\hline 5 & 87,22 & 97,22 \\
\hline 6 & 87,78 & 90 \\
\hline 7 & 84,44 & 97,22 \\
\hline 8 & 87,22 & 93,89 \\
\hline 9 & 87,78 & 91,11 \\
\hline \multicolumn{3}{|c|}{ Jika dilihat hasil perolehan skor pada } \\
\hline
\end{tabular}
setiap indikator, nampak bahwa kelas 17IDIQ memiliki skor yang lebih tinggi untuk semua indikatornya walaupun 
perbedaannya tidak terlalu jauh. Namun dapat disimpulkan bahwa sebenarnya dua kelas tersebut dapat dikatakan dapat membuat video pembelajaran yang menarik sesuai dengan indikator penilaian yang ada.

Berikut ini adalah beberapa contoh tampilan video animasi pembelajaran yang telah dibuat oleh mahasiswa dalam kelompoknya. Gambar 5, 6, 7 dan 9 berikut merupakan contoh-contoh tampilan video animasi yang disusun oleh mahasiswa.

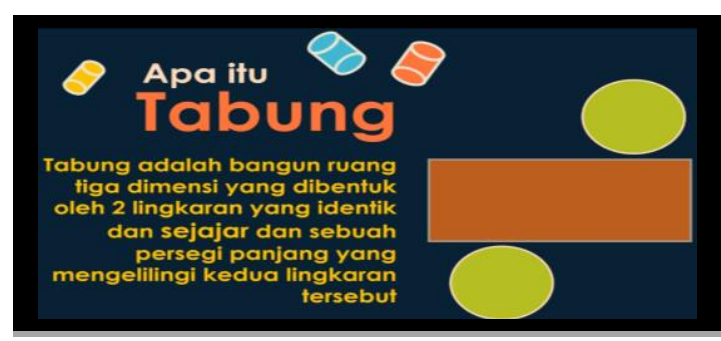

Gambar 5. Tampilan Video.

Pada Gambar 5, merupakan contoh tampilan awal dari video.

\section{Unsur-unsur Tabung}
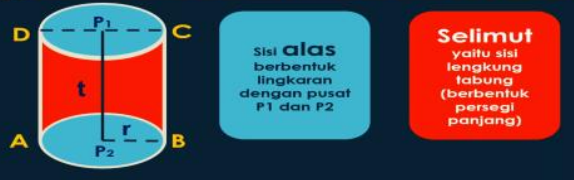

Gambar 6. Penjelasan Video.

Pada Gambar 6, berisikan penjelasan mengenai unsur-unsur dari bangun ruang.

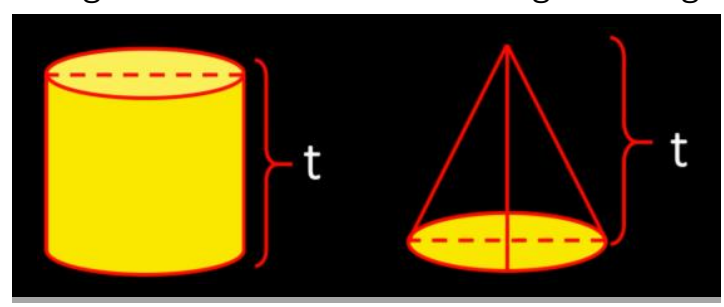

Gambar 7. Keterangan Simbol..
Sementara pada Gambar 7, mahasiswa juga menyantumkan simbol yang terdapat dalam bangun ruang.

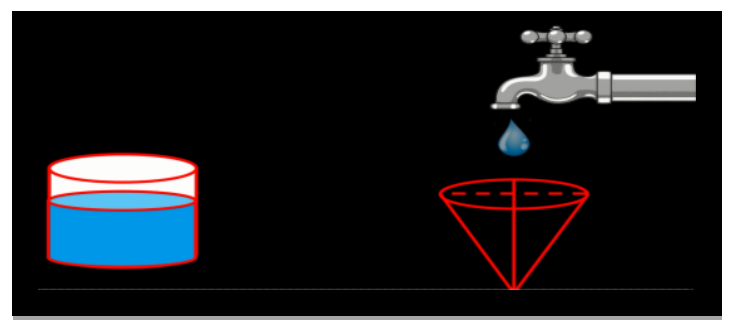

Gambar 8. Pemberian Animasi.

Gambar 8 merupakan tampilan animasi bergerak.

Mahasiswa menyusun mulai dari memberikan contoh-contoh benda-benda yang bentuknya sesuai dengan bangun ruang yang ada. Kemudian mahasiswa memberikan penjelasan bagaimana langkah dan cara untuk memperoleh rumus luas permukaan dan volume bangun ruang. Selain itu mahasiswa juga memberikan latihan yang dikerjakan oleh teman-temannya di kelas. Video pembelajaran juga di lengkapi dengan suara yang direkam, dengan disesuaikan dengan tampilan pada animasi.

Dengan fasilitas software yang ada, mahasiswa dapat membuat alat peraga yang menarik. Sehingga mereka juga dapat terlatih dan memiliki pengalaman untuk membuat alat peraga. Mahasiswa belajar untuk menyusun materi yang ada, selanjutnya membuat kerangkanya, membuat konsep pembuatan videonya, melakukan rekaman suara, memberikan efek suara dan memberikan kuis-kuis yang dapat dikerjakan melalui video pembelajaran tersebut. Ada beberapa masukan yang dapat diberikan kepada 
mahasiswa, antara lain adalah dalam memberikan suara, terkadang masih ada suara yang berisik sehingga suara saat penjelasan di video menjadi kurang jelas. Kemudian saat mahasiswa memberikan efek suara, masih terdapat video yang efeknya adalah suara efek lebih keras dari suara saat menjelaskan.

Hal lain yang menjadi kekurangannya adalah mengenai konten, masih terdapat beberapa kesalahan dalam mencantumkan rumus serta kunci jawaban pada soal kuis. Sehingga saat dipraktikkan di kelas masih ada beberapa mahasiswa yang bingung tentang materi serta langkah untuk mencari jawaban kuis.

Secara keseluruhan, video yang disusun menarik dan secara konten sudah layak untuk dapat digunakan untuk pembelajaran. Masukan lainnya adalah mahasiswa perlu mengerjakan secara kooperatif dengan teman-temennya dan dalam menyusun soal-soal perlu memperhatikan tingkat kesulitannya, bisa dilakukan dengan memilih soal yang dimulai dari tingkatan mudah, sedang kemudian sukar.

Dapat dikatakan mahasiswa juga dapat membuat video pembelajaran dengan baik karena memang sebelumnya mahasiswa juga pernah mendapat matakuliah yang berisikan pengajaran tentang membuat video pembelajaran yang menarik. Meskipun mahasiswa tidak memiliki latar belakang di bidang IT, namun secara keseluruhan mereka dapat membuat proyek video pembelajaran dengan baik.
Model pembelajaran PACE yang dirangkai untuk matakuliah Geometri ini sangat membantu sekali untuk mahasiswa. $\mathrm{Hal}$ ini sejalan dengan penelitian yang dilakukan oleh Suryana (2015), bahwa Model PACE dapat meningkatkan aspek kognitif mahasiswa, seperti representasi, abstraksi, berpikir kreatif dan pembuktian, serta afektif mahasiswa. Mahasiswa dapat belajar secara mandiri untuk mengembangkan kemampuannya, serta siap untuk menghadapi tantangan ke depan. Seperti saat sekarang, mahasiswa calon guru dituntut untuk memiliki keahlian dalam merangkai suatu media pembelajaran yang mampu membawa siswnya mencapai tujuan pembelajaran. Media pembelajaran yang saat ini sering digunakan adalah video animasi. Seperti penelitian yang dilakukan oleh Rahmayanti (2018) yang mengatakan bahwa video animasi dapat berpengaruh positif terhadap hasil belajar siswa. Sementara menurut Novita dan Putra (2017), yang mengatakan bahwa penggunaan video animasi sangat membantu guru dalam menjelaskan beberapa ilustrasi konsep penting pada siswa.

Namun yang menjadi pertanyaannya, bagaimana jika nantinya mahasiswa mendapatkan lokasi pengajaran di tempat yang kurang mendukung dalam fasilitas. Jawabannya adalah mahasiswa perlu belajar kreatif, karena banyak hal di sekitar yang dapat digunakan untuk belajar Geometri. Mahasiswa dapat 
memanfaatkan alat peraga, dari bendabenda disekitarnya.

\section{Penutup}

Penggunaan Model PACE pada pembelajaran Geometri materi bangun ruang dapat membantu mahasiswa untuk menjadi seseorang yang kreatif terlebih dalam membuat video pembelajaran. Penggunaan Model PACE dapat mendorong mahasiswa untuk mengembangkan kemampuannya dalam menghadapi tantangan ke depan sebagai calon guru sekolah dasar. Hal-hal yang perlu diperhatikan adalah dosen sebagai pengajar perlu bertindak secara konsisten dalam menerapkan langkah-langkah dari Model PACE.

\section{UCAPAN TERIMA KASIH}

Ucapan terimakasih kepada FIP UPH serta LPPM UPH yang memberikan dorongan dalam menuliskan jurnal ilmiah.

\section{Daftar Pustaka}

Arbain, N., \& Shukor, N. A. (2015). The Effects of GeoGebra on Students Achievement. Procedia - Social and Behavioral Sciences, 172. 208-214.

Daryanto. (2016). Media Pembelajaran

Peranannya Sangat Penting Dalam

Mencapai Tujuan Pembelajaran.

Yogyakarta: Gava Media.

Dasari, D. (2009). Meningkatkan Kemampuan Penalaran Statistis Mahasiswa Melalui Pembelajaran
Model PACE. Disertasi SPS UPI, Tidak Diterbitkan.

Fabiyi, T. R. (2017). Geometry Concepts in Mathematics Perceived Difficult to Learn By Senior Secondary School Students in Ekiti State, Nigeria. IOSR Journal of Research \& Method in Education (IOSRJRME), 07(01). 83-90. Janah, Sulasmono dan Setyaningtyas. (2019). Peningkatan Hasil Belajar Matematika Melalui Model Pembelajaran Problem Based Learning Berbantuan Media Video Siswa Kelas IV Sekolah Dasar. Jurnal Pendidikan Dasar, 7(1).

Kurniasih. (2017). Penerapan Strategi Pembelajaran Fase Belajar Model Van Hiele pada Materi Bangun Ruang Sisi Datar di SMP Islam Al-Azhaar Tulungagung. Jurnal Silogisme Kajian IImu Matematika dan Pembelajarannya, 2(2).

Lee, C. (1999). Computer-Assisted Approach for Teaching Statistical Concepts. Computers in the Schools, 16(1).

Mulyo, M. R. G. T., Sari, A. F., \& Syarifuddin, A. (2019). Proses Berpikir Siswa Bergaya Kognitif Visualizer dalam Menyelesaikan Masalah TIMSS Non Geometri. Mosharafa: Jurnal Pendidikan Matematika,8(1), 167178.

NCTM. (2000). Principles and Standards for School Mathematics (3rd ed.).

Novita, \& Putra. (2017). Peran Desain Learning Trajectory Nilai Tempat 
Bilangan Berbantukan Video Animasi Terhadap Pemahaman Konsep Nilai Tempat Siswa Kelas II SD. Jurnal Pendikan Matematika, 11(1).

Putra, A, E. (2015). Anak Berkesulitan Belajar di Sekolah Dasar Se-Kelurahan Kalumbuk Padang (Penelitian Deskriptif Kuantitatif). E-JUPEKhu: Jurnal Ilmiah Pendidikan Khusus, 4(1).

Rahman, A., \& Astria, Y. (2018). Penerapan

Model Pembelajaran Pace untuk Meningkatkan Kemampuan

Pembuktian Matematika Siswa Di

Kelas VII SMP Materi Geometri. Jurnal MAJU, 5(1).

Rahmayanti. (2018). Pengaruh

Penggunaan Media Video Animasi terhadap Hasil Belajar Siswa Kelas V SDN Se-Gugus Sukodono Sidoarjo. Jurnal Penelitian Pendidikan Guru Sekolah Dasar, 6(4).

Saragih, M., Tamba, K., \& Hidayat, D. (2019). Implikasi Pendidikan yang Berpusat pada Kristus dalam Kelas Matematika. JOHME: Journal of Holistic Mathematics Education, 2(2).

Setianingrum. (2017). Penggunaan Variasi Media Ajar Terhadap 3 Gaya Belajar Siswa dalam Pembelajaran Bahasa Jepang. JAPANEDU: Jurnal Pendidikan dan Pengajaran Bahasa Jepang, 2(1).

Sholihah, S. Z., \& Afriansyah, E. A. (2017). Analisis kesulitan siswa dalam proses pemecahan masalah geometri berdasarkan tahapan berpikir Van Hiele. Mosharafa: Jurnal Pendidikan Matematika, 6(2), 287-298.
Sundawan, M. D., Irmawan, W., \& Sulaiman, H. (2019). Kemampuan Berpikir Relasional Abstrak Calon Guru Matematika dalam Menyelesaikan Soal-Soal Non-Rutin pada Topik Geometri Non-Euclid. Mosharafa: Jurnal Pendidikan Matematika,8(2), 319-330.

Suryana. (2013). Penerapan Model Pembelajaran PACE dalam Meningkatkan Kemampuan Berpikir Kreatif Matematis. Prosiding SNMPM Universitas Sebelas Maret, Vol. 1.

Suryana. (2015). Analisis Implementasi Model Pace pada Mata Kuliah Statistika Matematika. JKPM: Jurnal Kajian Pendidikan Matematika, 01(01).

Susanto. (2013). Teori Belajar \& Pembelajaran. Jakarta: Prenadamedia Group.

\section{Riwayat Hidup Penulis}

Tanti Listiani, M.Pd.

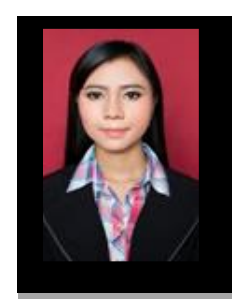

Lahir di Kabupaten Magelang, Jawa Tengah. Saat ini masih aktif menjadi staf pengajar di Fakultas IImu Pendidikan Universitas Pelita Harapan Tangerang. Riwayat Pendidikan untuk studi S1 yaitu jurusan Pendidikan Matematika dari Universitas Kristen Satya Wacana Salatiga, lulus pada tahun 2013 dan melanjutkan S2 Pendidikan Matematika di Universitas Sebelas Maret, Surakarta yang lulus pada tahun 2015. 